\title{
A Panel Data Investigation of Real Exchange Rate Misalignment and Growth
}

\section{Flávio Vilela Vieira}

Professor - Instituto de Economia da Universidade Federal de Uberlândia (UFU) e Pesquisador do CNPq - Endereço para contato: Av. João Naves de Ávila, 2121 - Campus Santa Mônica, Bloco J - Uberlândia - MG - CEP: 38400-902 - E-mail: flaviovieira@ufu.br

\section{Ronald MacDonald}

Adam Smith Chair of Political Economy - Department of Economics - University of Glasgow Adam Smith Building - University of Glasgow, G12 8RT - Glasgow - UK Email: ronald.macdonald@glasgow.ac.uk

Recebido em 11 de julho de 2011 . Aceito em 06 de junho de 2012.

\begin{abstract}
The paper investigates the role of real exchange rate misalignment on long-run growth for a set of ninety countries using time series data from 1980 to 2004 . We first estimate a panel data model (fixed and random effects) for the real exchange rate in order to produce estimates of the equilibrium real exchange rate and this is then used to construct measures of real exchange rate misalignment. We provide an alternative set of estimates of RER misalignment using panel cointegration methods. The results for the two-step System GMM panel growth models indicate that the coefficients for real exchange rate misalignment are positive for different model specification and samples, which means that a more depreciated (appreciated) real exchange rate helps (harms) long-run growth. The estimated coefficients are higher for developing and emerging countries.
\end{abstract}

\section{Keywords}

economic growth, real exchange rate misalignment, panel data analysis

\section{JEL Classification}

F31, O47, C33

\section{Resumo}

O trabalho investiga o papel do desalinhamento da taxa de câmbio real no crescimento de longo prazo para um conjunto de noventa países para o período de 1980 a 2004. Primeiramente estima-se um modelo de dados em painel (efeitos fixos e aleatórios) para a taxa de câmbio real, no intuito de se obter estimações da taxa de câmbio real de equilíbrio que são utilizadas para construir as medidas de desalinhamento da taxa de câmbio real. O trabalho utiliza também estimações adicionais do desalinhamento da

- O trabalho foi desenvolvido durante o pós-doutorado na University of Glasgow com Bolsa de Pós-Doutorado no Exterior da CAPES. 
taxa de câmbio real com base em análise de cointegração em painel. Os resultados dos modelos de crescimento em painel (two-step System GMM) indicam que os coeficientes do desalinhamento da taxa de câmbio real são positivos para diferentes especificações e amostras, indicando que uma taxa de câmbio real mais depreciada (apreciada) estimula (prejudica) o crescimento de longo prazo. Os coeficientes estimados são maiores para os países emergentes e em desenvolvimento.

\section{Palavras-Chave}

crescimento econômico, desalinhamento da taxa de câmbio real, análise de painel

\section{Introduction}

The real exchange rate does not normally feature in economic growth models, particularly those founded in the neoclassical tradition. Its role has, however, been highlighted by the literature on export-led growth since one of the policy recommendations in this literature is that it is crucially important that the price of export goods and services is at a level that makes it attractive to shift resources into their production. Other studies in the real exchange rate and growth literature are devoted to examining the effect of real exchange volatility on trade and investment and ultimately on growth. High real exchange rate volatility is also part of the investigation on the occurrence of currency crises episodes and how this can have a negative impact on growth.

The empirical literature on exchange rate misalignment and growth is not an extensive one but it has grown recently after the experience of several countries adopting pegged exchange rates as a key element in their disinflation policies. The outcome of such pegged exchange rate regimes is frequently associated with real exchange rate appreciation and the adverse impact this has on the external balance. One of the main arguments in favor of shifting from pegged to flexible exchange rates is that such a move is followed by a nominal and real depreciation, which helps foster long-run economic growth. Another reason for the growing interest in real exchange rate misalignment and growth is the experience of real exchange rate appreciation for many currencies over the recent past when the U.S. dollar has been on a trend depreciation path due to its fiscal and current account deficits. 
This paper empirically investigates the relationship between real exchange rate misalignment and long-run economic growth for a set of almost one hundred countries using panel data techniques, including fixed and random effects, panel cointegration and system GMM. One of the main empirical contributions of the paper is to test different model specifications for the long-run equilibrium real exchange rate and then use these to obtain estimated real exchange rate misalignments and assess how robust the results are when they are included as an explanatory variable in the panel growth model. We have also estimated the growth models using System GMM and correct for the case of too many instruments which is an important econometric issue and has not to our knowledge been considered in this literature before.

The empirical results indicate that the coefficients for different measures of real exchange rate misalignment are positive for all estimated models and statistically significant for most model specifications and different samples, meaning that a more depreciated real exchange rate enhances long-run growth. The estimated coefficients for real exchange rate misalignment are higher for developing countries in most models, suggesting that the benefits for such countries are greater in terms of fostering long-run growth. The paper is divided in four sections, including the introduction and concluding remarks. Section two develops a literature review on real exchange rate misalignment and growth. Section three is dedicated to the empirical results including the estimation of the real exchange rate misalignments and the panel growth models for the complete sample and for a set of developing and emerging economies.

\section{Real Exchange Rate Misalignment and Growth: A Literature Review}

The literature on real exchange rate equilibrium goes back to the 1960s (Balassa, 1964) and the second half of the first decade of the new century has shown an increase in the number of empirical studies on real exchange rate misalignment and growth. ${ }^{1}$ The notion

\footnotetext{
1 See Rodrik (2008), Eichengreen (2008), Berg and Miao (2010), Gala and Lucinda (2006), and Aghion et. al (2006) for recent panel data studies on real exchange rate misalignment and growth. On the role of exchange rate regimes and misalignments in developing countries, see Coudert and Couharde (2008).
} 
of real exchange rate equilibrium is normally associated with the combination of external (current account sustainability) and internal (intertemporal equilibrium in the goods market) balance. The literature on exchange rate misalignment has not reached a consensus in terms of how misalignment is measured, since part of the literature is based on deviations from PPP while other studies focus on the deviation of the real exchange rate from some equilibrium level. ${ }^{2}$ Another issue that is frequently examined in the literature on real exchange rate misalignment is the notion that overvaluation processes that last for a significant period of time are good indicators of possible currency crises (Frankel and Rose, 1996) and ultimately have an impact on relative price adjustment and create a negative correlation with growth.

One of the early studies on exchange rate misalignment and growth is Razin and Collins (1997) who argue that the policy of keeping the real exchange rate depreciated is generally associated with competitive devaluation policies to stimulate a country's export sector. Edwards (1989) investigates the relationship between real exchange rates and growth and one of the main findings is that inadequate (misaligned) real exchange rates are associated with relative price distortions in the tradable and non-tradable goods sectors and the outcome is a non-optimum allocation of resources among different sectors of the economy, which has a negative impact on growth. ${ }^{3}$

Rodrik (2008) is one of the recent studies on real exchange rate misalignment and growth, with estimation results for a set of 184 countries and time series data from 1950 to 2004. The author develops an index to measure the degree of real exchange rate undervaluation adjusted for the Balassa-Samuelson effect using real per capita GDP (RGDPCH - Penn World Table) data. The main empirical result is that growth is higher in countries with more undervalued real exchange rates and the effect is linear and similar for both under and overvaluation, implying that an overvalued real exchange rate hurts

\footnotetext{
2 SeeEdwards and Savastano (1999) for a review of the literature on exchange rate misalignment. 3 See Clark and MacDonald (1988) for a description of the BEER (Behavioral Equilibrium Exchange Rate) approach to measure real exchange rate misalignment. The idea is to estimate a long-run relationship between the real effective exchange rate and its fundamentals, where the equilibrium exchange rate is allowed to change over time based on changes in economic fundamentals and domestic policies. The BEER and the fundamental equilibrium exchange rate (FEER) provide useful information on the selection of the main determinants of the real exchange rate: per capita real GDP (Balassa-Samuelson effect), net foreign assets, the terms of trade and government consumption.
} 
growth while an undervalued rate fosters growth. The magnitude and statistical significance of the estimated coefficient for real exchange rate undervaluation is higher for developing countries due to the fact that such countries are often characterized by institutional fragility and market failures. ${ }^{4}$

Berg and Miao (2010) develop an empirical investigation on real exchange rate misalignment and growth in order to compare the results with Rodrik (2008) and what they call the Washington Consensus (WC) view, which is based on a fundamental equilibrium exchange rate model (FEER). ${ }^{5}$ Their main result suggests that both views are observationally equivalent for the main growth regressions but there are some identification problems since the determinants of real exchange rate misalignments are also likely to be explanatory variables in the growth regression. The empirical findings support those from Rodrik (2008) in the sense that undervaluation helps foster long-run growth and overvaluation has the opposite effect, a result that it is not consistent with the WC view. The authors argue that once they disentangle the direct and the indirect effects of the factors that drive growth the evidence is in favor of the WC view.

Eichengreen (2008) develops a historical review of the literature on real exchange rate and growth, focusing attention on possible channels through which the real exchange rate might have an impact on long-run economic growth. The author argues in favor of a more depreciated real exchange rate as long as this is not associated with higher exchange rate volatility. The combination of a depreciated real exchange rate and low volatility is regarded as a favorable combination for developing and emerging economies, where a more dynamic export sector is usually an important part of the process for achieving higher and sustained economic growth rates. ${ }^{6}$ The main policy

${ }^{4}$ Rodrik (2008) incorporates other variables in the growth models (panel and cross-section regressions), including: lagged growth, initial income level (convergence), institutions (Rule of Law), government consumption, terms of trade, inflation, gross domestic saving, years of education, time and country dummies.

5 The first measure of real exchange rate misalignment $\left(\varepsilon_{i t}^{P P P}\right)$ is the same as in Rodrik (2008), using RGDPCH to capture the Balassa-Samuelson effect, while the second measure $\left(\varepsilon_{i t}^{F E R R}\right)$ is based on the FEER view and incorporates additional variables (terms of trade, openness, investment and government consumption).

6 See Aghion et. al (2006) on real exchange rate volatility and factor productivity, which is different from the impact on factor accumulation (growth). The authors found that countries with a significant degree of real exchange rate variability experience slower productivity growth and the magnitude of such is negatively associated with the degree of financial development. 
recommendation therefore is for such countries is to keep their real exchange rate at a competitive level and with lower volatility since they are relevant for jump-starting growth based on development experiences, such as the high growth East Asian economies.

The work developed by Aguirre and Calderón (2006) is among those using a measure of exchange rate misalignment based on the residuals from a FEER regression and they use dynamic panel and cointegration analysis for a set sixty countries with data from 1965 to 2003. The empirical evidence suggests that the effect of RER misalignment on growth is non-linear, which means that when real exchange rate depreciation is too high the impact on growth is negative but when it is small or moderate it can be growth enhancing.

Gala and Lucinda (2006) developed a dynamic panel data analysis using Difference and System GMM techniques, for a set of 58 countries from 1960 to 1999, with a measure of real exchange rate misalignment incorporating the Balassa-Samuelson effect and other control variables for the growth regression such as physical and human capital, institutional environment, inflation, the output gap and terms of trade shocks. The main empirical evidence supports the argument that a real depreciated (appreciated) exchange rate is associated to higher (lower) growth rates.

One of the main contributions of our empirical estimates in the next section is to extend the determinants of real exchange rates including not only differences in per capita income but also the terms of trade, net foreign assets and government consumption. ${ }^{8}$ We have also estimated the growth models using System GMM and correcting for too many instruments (Tables 3 and 6) based on the Hansen-Diff test ( $\mathrm{p}$-value close to one) which has not been reported in recent studies (Rodrik, 2008; Berg and Miao, 2010).

\footnotetext{
7 Hausmann et. al (2005) also investigate a non-linear relationship for real exchange rate misalignment and growth for eighty episodes when growth accelerates by at least two percentage points and that acceleration lasts for at least eight years. Their main empirical finding is that real exchange rate depreciation is one of the factors associated with the occurrence of such growth accelerating episodes.

8 Berg and Miao (2010) include terms of trade, openness, government consumption and investment as additional explanatory variables for growth but not net foreign assets.
} 


\section{The Empirics of Real Exchange Rate Misalignment and Growth}

In this section we outline the empirics of measuring real exchange rate misalignments and the estimation of per capita GDP growth models using System GMM.

\subsection{Real Exchange Rate Misalignment and Growth: Panel Data Esti- mation}

In calculating the real exchange rate we follow the procedure suggested by Rodrik (2008) and use data from the Penn World Tables 6.2 for the nominal exchange rates (XRAT) and PPP conversion factors (PPP) to calculate a real exchange rate (RER): ${ }^{9}$

$$
\mathrm{LRER}_{i t}=L\left(\mathrm{XRAT}_{i t} / \mathrm{PPP}_{i t}\right)
$$

where $i$ is a country index and $t$ is an index for (5-year) time periods; XRAT and PPP are expressed as national currency units per U.S. dollar; L indicates that the variable is in logs.

When RER is greater than one it means that the value of the currency is lower (more depreciated) than is indicated by purchasing-power parity. Given the so called Balassa-Samuelson (BS) effect, we know that non-traded goods are also cheaper in poorer countries, which requires an adjustment to take this into account. In order to capture the BS effect we run a regression of RER on per capita GDP (RGDPCH):

$$
\operatorname{LRER}_{i t}=\alpha+\beta L \operatorname{RGDPCH}_{i t}+\mathrm{f}_{t}+\mathrm{u}_{i t}
$$

where $f_{t}$ is a time fixed effect and $u_{i t}$ is the error term.

The estimation of Equation (2) provides the estimated coefficient for $\beta$ and if the coefficient is negative and statistically significant this can be taken as an indication of the relevance of the BS effect (Table 1, Model 1). The final step in constructing an index of undervaluation (misalignment) is to calculate the difference between the actual real exchange rate from Equation (1) and the exchange

9 The definition of real exchange rate as units of domestic currency relative to the U.S. dollar means that a higher (lower) value is associated to real exchange rate depreciation (appreciation). 
rate adjusted by the BS effect from Equation (2), which we call Misl.

We have used other model specifications in order to obtain additional measures of RER misalignment and we use the Hausman test to select which one is the preferred estimation. The data refers to a set of ninety countries, where twenty four are developed countries and the remaining sixty six countries are developing and emerging countries. The time series dimensions of our data set are 1980-2004.

The seven different model specifications used in Table 1 and the motivation for the inclusion of the explanatory variables is based on theoretical and empirical lessons from the literature on real exchange rate determinants. The real GDP per capita (LRGDPCH) is included to capture the Balassa-Samuelson effect where countries with relative higher levels of per capita GDP are supposed to experience a real exchange rate appreciation over time, which is associated to a negative estimated coefficient. The net foreign asset (NFAGDP) variable is used as a proxy to capture external (current account) adjustment and countries with better current account position should face real exchange appreciation over time, which is associated with a negative estimated coefficient. Terms of trade (LTT) improvements are associated to higher ratios of export to import prices and ceteris paribus, with better trade performance and real exchange rate appreciation over time (negative estimated coefficient). Finally, the inclusion of government consumption (LGOV) seeks to capture changes in the composition of demand since it is generally thought to fall more heavily on non-traded goods and given that such goods are more supply inelastic, the outcome is a real exchange rate appreciation (negative estimated coefficient).

Table 1 reports the estimated real exchange rate for seven different model specifications, where in five of them the Hausman test indicates the fixed effect model as the preferred one (Models 2, 3, 5, 6 and 7) while the random effect model was selected for Models 1 and 4. The coefficient on real per capita GDP (LRGDPCH) is statistically significant in Model 1 , when it is the only explanatory variable, and it appears with a negative estimated coefficient $(-0.301)$. This is higher than when it is included with other variables (Models 2, 3 and 5), although in these cases the coefficient is insignificant. All the other estimated coefficients for NFAGDP, LTT and LGOV are 
statistically significant in different model specifications and with the expected coefficient signs.

Table 1 - Model Estimation for Real Exchange Rate (log)

\begin{tabular}{lccccccc}
\hline Variables & Model 1 & Model 2 & Model 3 & Model 4 & Model 5 & Model 6 & Model 7 \\
\hline Hausman (FE x RE) & RE & FE & FE & RE & FE & FE & FE \\
LRGDPCH & $-0.301^{* * *}$ & -0.109 & -0.043 & & -0.019 & & \\
& $(-11.51)$ & $(-1.59)$ & $(-0.62)$ & & $(-0.26)$ & & \\
NFAGDP & & $-0.100^{* * *}$ & $-0.089^{* *}$ & $-0.135^{* * *}$ & $-0.106^{* * *}$ & $-0.121^{* * *}$ & $-0.2613^{* * *}$ \\
& & $(-2.93)$ & $(-2.43)$ & $(-4.51)$ & $(-2.87)$ & $(-3.68)$ & $(-3.08)$ \\
LTT & & $-0.281^{* * *}$ & & $-0.259^{* * *}$ & & $-0.2613^{\star * *}$ \\
& & & $(-4.38)$ & & $(-3.98)$ & & $(-4.04)$ \\
LGOV & & & & $-0.135^{* *}$ & $(-3.29)$ & $-0.1385^{\star * *}$ \\
& & & & & $(-2.05)$ & $(-3.29)$ & $(-2.14)$ \\
\hline
\end{tabular}

Notes: t-stat (FE) and z-stat (RE) in parenthesis.

$\mathrm{RE}$ and FE refers to Random and Fixed effect estimation.

$*, * *$ and ${ }^{* * *}$ indicates significance at $10 \%, 5 \%$ and $1 \%$

Econometric Software - Stata 10

We consider this first set of results as an indication that empirical studies such as Rodrik (2008), who uses only LRGDPCH as an explanatory variable to estimate the equilibrium real exchange rate and then calculate the real exchange rate misalignment (undervaluation), should be extended to include other determinants of the real exchange rate. In order to measure real exchange rate misalignment we then subtract the actual real exchange rate from its estimated value using the coefficients from Table 1 (Misl, Mis2, Mis3, Mis4, Mis5, Mis6 and Mis7). The main purpose of this transformation is to investigate the role of such measures of RER misalignment in our growth models for the complete (Table 2) and developing and emerging (Table 3) samples, based on a two-step robust System GMM estimation.

The option to use System GMM is based on the argument that the existence of weak instruments implies asymptotically that the variance of the coefficient increases and in small samples the coefficients can be biased. To reduce the potential bias and inaccuracy associated with the use of Difference GMM (Arellano and Bond, 1991), Arellano and Bover (1995) and Blundell and Bond (1998) 
develop a system of regressions in differences and levels. The instruments for the regression in differences are the lagged levels of the explanatory variables and the instruments for the regression in levels are the lagged differences of explanatory variables. These are considered as appropriate instruments under the assumption that although there may be correlation between the levels of explanatory variables and the country specific effect, there is no correlation between those variables in differences and the country specific effect.

The objective here is to first estimate a simple growth model for each of our seven measures of RER misalignment and then include the lagged dependent variable and initial income level. The next step is to estimate an extended model for each measure of RER misalignment including other variables such as: years of education (human capital), law and order (institutions), government consumption (fiscal discipline) and inflation (macroeconomic stability). ${ }^{10}$

The estimated results for the complete sample reported in Table 2 show that all estimated coefficients for the RER misalignment are positive, meaning that a more depreciated real exchange rate helps foster long-run growth. The results are robust since most of the coefficients are statistically significant for different measures of RER misalignment and model specification. For the models where misalignment is an explanatory variable with lagged growth and initial income, the estimated coefficients range from 0.204 to 0.085 and the average is 0.146 , while for the extended models the range is from 0.103 to 0.026 with an average RER misalignment of 0.071 , which is half of the average for the simple models. If we consider the average coefficients for RER misalignment for the simple and extended models, a $10 \%$ increase in real exchange rate misalignment increases growth from a range of $0.7 \%$ to $1.4 \%$ over a five year period, which means that the average annual increase in growth varies from $0.14 \%$ to $0.28 \%$.

\footnotetext{
${ }^{10}$ The choice of different growth model specifications reported on Tables 2, 3 and 6 is based on the idea of first, estimate more parsimonious models with the lagged dependent variable (dynamic models), initial income (convergence) and one measure of real exchange rate misalignment, which are represented by Models 1, 3, 5, 7, 9, 11 and 13 for Tables 2 and 3 . The next step is to expand such models with other explanatory variables based on empirical findings from the literature, including a proxy for human capital (EDUC), institutions (LAW), government consumption (GOV) and inflation (INF), which are represented by Models 2, 4, 6 and 8, while Models 10, 12 and 14 do not include GOV since we have used such variable as one of the real exchange rate determinants in Table 1 . The same model specification applies for the growth models in Table 6 using the two measures of exchange rate misalignment from the cointegration analysis.
} 


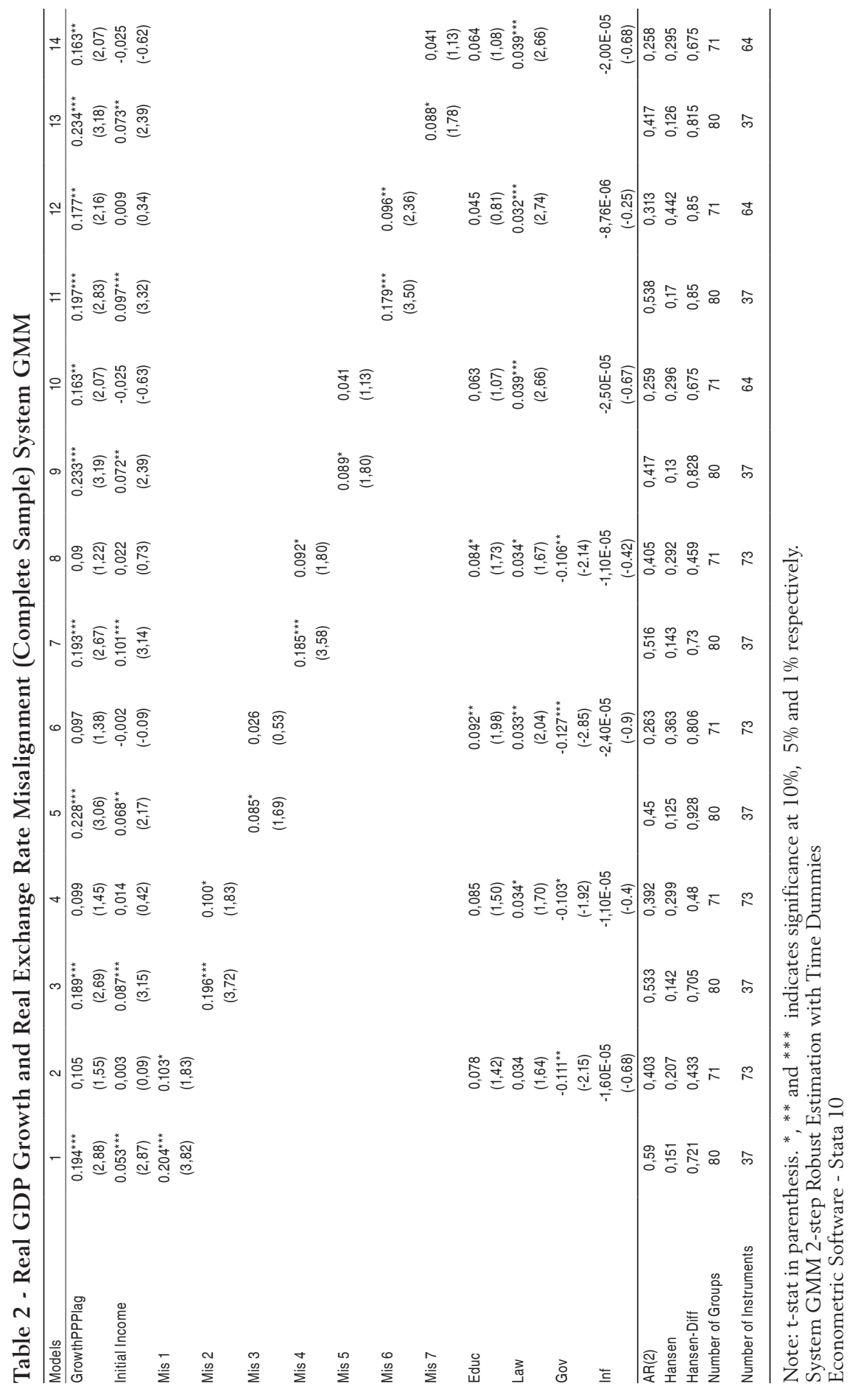

Est. Econ., São Paulo, vol. 42, n.3, p. 433-456, jul.-set. 2012 
Table 3 reports the estimated results for developing and emerging countries and it shows that all estimated coefficients for RER misalignment are positive, indicating that a more depreciated real exchange rate helps foster long-run growth.

The estimated coefficients for RER misalignment are all statistically significant for the models where misalignment is an explanatory variable with lagged growth and initial income, and the estimated coefficients range from 0.253 to 0.120 with an average value of 0.172 . For the extended models the estimated coefficients for RER misalignments are not statistically significant, except for Mis6, where they range from 0.18 to 0.05 , with an average of 0.112 . The lack of statistical significance for the extended models are associated with the fact that for such models we have to deal with instrument proliferation (Roodman, 2009), which was not the case when estimating the extended model for the complete sample in Table 2. If we consider the average coefficients for RER misalignment for the simple and extended models, a 10\% real exchange rate depreciation increases growth from a range of $1.1 \%$ to $1.7 \%$ over a five year period, which means that the average annual increase in growth varies from $0.22 \%$ to $0.34 \%$. 


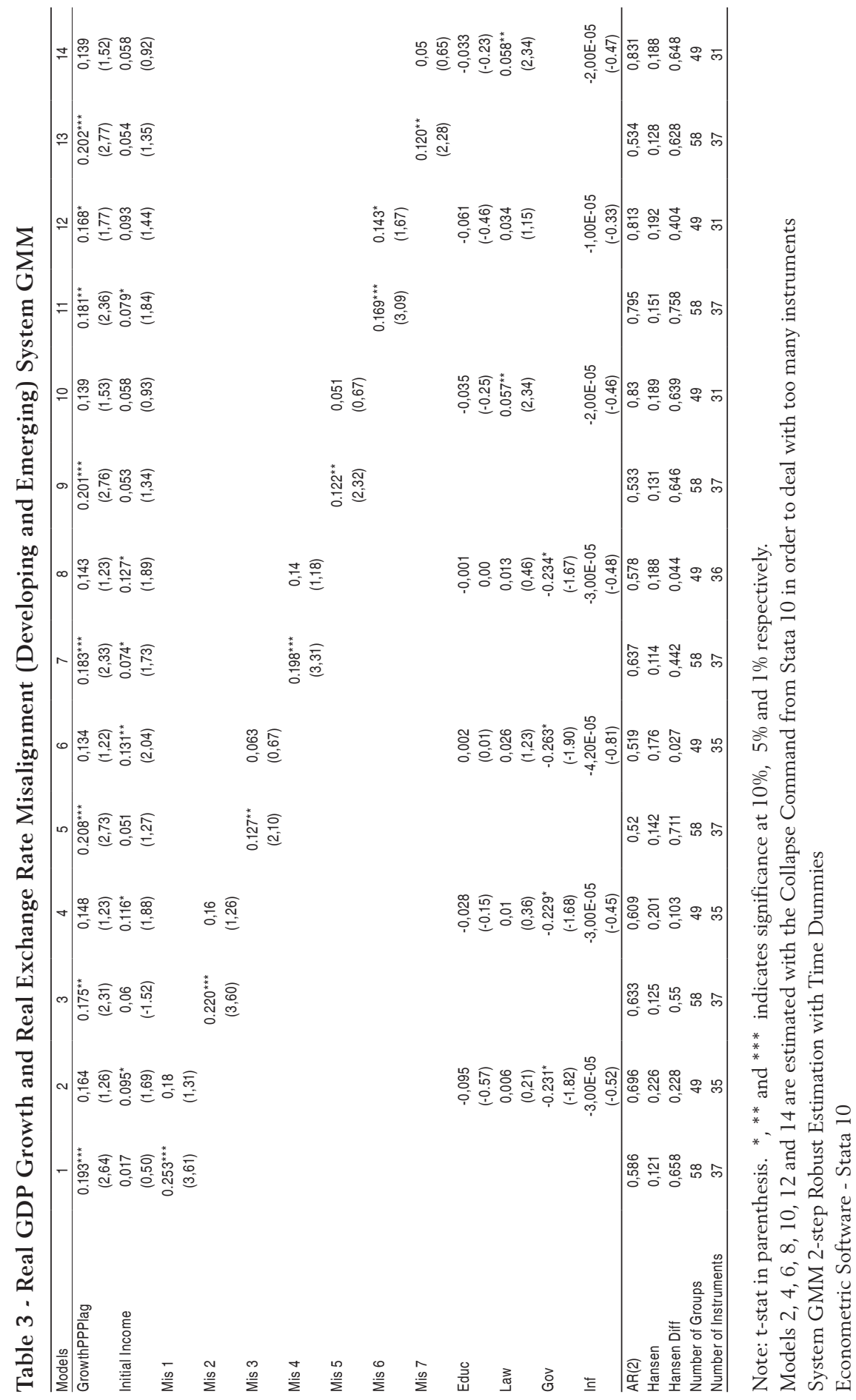


Comparing the results for the complete sample and the developing and emerging countries, it is clear that the estimated coefficients for RER misalignment are higher for developing and emerging countries, suggesting that a policy based on sustaining a depreciated real exchange rate has a long-run impact on growth that is magnified for such countries. Our first set of empirical results on the role of RER misalignment for long-run growth supports the findings from other recent studies, such as Rodrik (2008), Berg and Miao (2010), Aguirre and Calderón (2006), Gala and Lucinda (2006) and Eichengreen (2008) in the sense that an undervalued real exchange rate is beneficial for long-run growth, while the opposite is true for an overvalued real exchange rate. On the other hand, our estimated models have provided additional empirical evidence that long-run equilibrium exchange rates should not be modeled only as a function of real per capita GDP (Rodrik, 2008), but should include other determinants, such as the terms of trade, net foreign assets and government consumption.

\subsection{Real Exchange Rate Misalignment and Growth: Panel Unit Roots and Cointegration}

The aim of this section is to use panel cointegration analysis to calculate the RER misalignment and then estimate the panel growth models to see how robust the results are when compared to those from the previous section in terms of the magnitude and significance of the estimated coefficients.

\subsubsection{Unit Roots and Panel Cointegration Tests}

The first step is to use apply a range of panel unit root tests (the Levin, Lin and Chu 2002 test; the Im, Pesaran and Shin, 2003 W-Stat; and two Fisher-type tests using ADF and PP tests from Maddala and $\mathrm{Wu}, 1999$; and Choi, 2001). The results for each one of our five variables are reported in Table 4, where all the tests have a unit root under the null hypothesis. We note that for real per capita GDP and net foreign assets there is no contradiction among the unit root tests as both are non-stationary. For the real exchange rate, 
terms of trade and government consumption there are mixed results regarding the non-stationarity of each variable. ${ }^{11}$

Table 4 - Panel Unit Roots Tests

\begin{tabular}{lccccc}
\hline Variables & Method & Statistic & Prob. ${ }^{*}$ & Obs & Non-Stationary or Stationary \\
\hline LRER & Levin, Lin \& Chu & $-1,0739$ & 0,1414 & 2144 & NST \\
& Im, Pesaran and Shin W-stat & $-1,39674$ & 0,0812 & 2144 & NST \\
& ADF - Fisher Chi-square & 280,064 & 0,000 & 2144 & ST \\
& PP - Fisher Chi-square & 254,367 & 0,0002 & 2160 & ST \\
\hline LRGDPCH & Levin, Lin \& Chu & 1,25344 & 0,895 & 2134 & NST \\
& Im, Pesaran and Shin W-stat & 4,11483 & 1,000 & 2134 & NST \\
& ADF - Fisher Chi-square & 133,638 & 0,996 & 2134 & NST \\
& PP - Fisher Chi-square & 154,707 & 0,914 & 2160 & NST \\
\hline NFAGDP & Levin, Lin \& Chu & 3,59056 & 0,9998 & 2126 & NST \\
& Im, Pesaran and Shin W-stat & 4,95657 & 1,000 & 2126 & NST \\
& ADF - Fisher Chi-square & 113,564 & 1,000 & 2126 & NST \\
& PP - Fisher Chi-square & 129,845 & 0,9981 & 2159 & NST \\
\hline LTT & Levin, Lin \& Chu & $-54,9557$ & & 1796 & ST \\
& Im, Pesaran and Shin W-stat & $-3,14395$ & 0,0008 & 1796 & ST \\
& ADF - Fisher Chi-square & 167,119 & 0,5908 & 1796 & NST \\
& PP - Fisher Chi-square & 221,803 & 0,0062 & 1857 & ST \\
\hline LGOV & Levin, Lin \& Chu & $-0,3778$ & 0,3528 & 2117 & NST \\
& Im, Pesaran and Shin W-stat & 1,47413 & 0,9298 & 2117 & NST \\
& ADF - Fisher Chi-square & 164,954 & 0,7825 & 2117 & NST \\
& PP - Fisher Chi-square & 260,206 & 0,0001 & 2143 & ST \\
\hline
\end{tabular}

* Probabilities for Fisher tests are computed using an asymptotic Chi-square distribution. All other tests assume asymptotic normality.

Im, Pesaran and Shin; ADF - Fisher and PP - Fisher - Null Hypothesis: Unit Root (Individual Unit Root process).

Levin, Lin \& Chu Test - Null Hypothesis: Unit Root (common Unit Root process).

Automatic lag length selection based on Modified Schwarz Criteria and Bartlett kernel.

Econometric Software - Eviews 6.

The recent literature has focused on tests of cointegration in a panel setting and we provide the results in Table 5 for two panel cointegration tests based on Pedroni (1999) (2004) and Kao (1999), where both are Engle-Granger based tests. The cointegration tests proposed by Pedroni (1999) (2004) allow for heterogeneous intercepts and trend coefficients across cross-sections, with different methods of constructing statistics for testing the null hypothesis of no cointegration. There are two alternative hypotheses: the homogenous alternative which is called the within-dimension test, or panel statistics test, and the heterogeneous alternative referred to as the betweendimension, or group statistics test. This type of panel cointegration

${ }^{11}$ We have also used the Hadri (2000) unit root test, where stationarity is the null hypothesis and we reject the null for all five variables. 
test has the advantage over others that it allows for heterogeneous variances across countries at each point in time allowing to pool the long-run information contained in the panel, while permitting the short-run dynamics to vary among different groups. The Kao (1999) test follows the same basic approach but specifies cross-section specific intercepts and homogeneous coefficients in the first-stage regressors. The panel cointegration results from Table 5 provide us with evidence of cointegration since most of Pedroni test statistics reject the null hypothesis of no cointegration for the two estimated models and the same interpretation can be drawn from the Kao test statistics where the null is rejected in both cases. ${ }^{12}$

Table 5 - Panel Cointegration Tests: Pedroni and Kao

\begin{tabular}{|c|c|c|c|}
\hline Model 1: LRER, LRGDPCH and NFAGDP & Pedroni & Statistics & Prob. \\
\hline \multicolumn{4}{|c|}{ Alternative hypothesis: common AR coefs. (within-dimension) } \\
\hline & Panel v-Statistic & 3,482 & 0,000 \\
\hline & Panel rho-Statistic & $-0,890$ & 0,187 \\
\hline & Panel PP-Statistic & $-5,997$ & 0,000 \\
\hline & Panel ADF-Statistic & $-7,576$ & 0,000 \\
\hline \multicolumn{4}{|c|}{ Alternative hypothesis: individual AR coefs. (between-dimension) } \\
\hline & Group rho-Statistic & 3,907 & 1,000 \\
\hline & Group PP-Statistic & $-1,999$ & 0,023 \\
\hline & Group ADF-Statistic & $-7,216$ & 0,000 \\
\hline & Kao & Statistics & Prob. \\
\hline & $\mathrm{ADF}$ & $-8,473$ & 0.000 \\
\hline Model 2:LRER, LRGDPCH, NFAGDP, LTT and LGOV & Pedroni & Statistics & Prob. \\
\hline \multicolumn{4}{|c|}{ Alternative hypothesis: common AR coefs. (within-dimension) } \\
\hline & Panel v-Statistic & $-0,048$ & 0,519 \\
\hline & Panel rho-Statistic & 9,363 & 1,000 \\
\hline & Panel PP-Statistic & $-2,686$ & 0,004 \\
\hline & Panel ADF-Statistic & $-3,655$ & 0,000 \\
\hline \multicolumn{4}{|c|}{ Alternative hypothesis: individual AR coefs. (between-dimension) } \\
\hline & Group rho-Statistic & 13,788 & 1,000 \\
\hline & Group PP-Statistic & $-0,416$ & 0,339 \\
\hline & Group ADF-Statistic & $-3,568$ & 0,000 \\
\hline & Kao & Statistics & Prob. \\
\hline & DF & $-6,6135$ & 0,000 \\
\hline & $\mathrm{DF}^{*}$ & $-6,4649$ & 0,000 \\
\hline
\end{tabular}

Null Hypothesis: No Cointegration.

Pedroni Test: Automatic lag length selection based on SIC with a max lag of 4 .

Kao Test: Automatic lag length selection based on SIC: 5 for model 1 and 0 for model 2.

Pedroni and Kao Tests: Newey-West automatic bandwidth selection and Bartlett kernel.

Pedroni and Kao Tests - Trend assumption: No deterministic trend.

Econometric Software - Eviews 6.

12 The choice of the two model specifications for the cointegration analysis developed in Table 5 was based on the idea of first, estimate a model including the Balassa-Samuelson effect (LRGDPCH) and a proxy variable for the external adjustment (NFAGDP) since they are used in most empirical models of equilibrium exchange rate. The second model includes the additional variables that we have specified as determinants of the equilibrium real exchange rate (Table 1). Other model specifications are possible but this will result in additional measures of real exchange rate misalignment and we evaluate that nine measures are sufficient to provide robust evidence on their impact on growth. 
Having estimated the panel unit root and cointegration tests we then estimate a vector error correction model (VECM) for the two model specifications reported in Table 5 (Models 1 and 2) in order to obtain the two measures of real exchange rate misalignment (MisCoint 1 and MisCoint 2) as the difference between the actual and predicted real exchange rate. ${ }^{13}$

\subsubsection{Growth and Real Exchange Rate Misalignment: System GMM Estimation}

The results for our two-step System GMM growth model are reported in Table 6 using the two measures of RER from the VECM and they indicate that the estimated coefficients are positive and the results are robust for different models and sets of countries. This evidence therefore supports the previous estimated results (Tables 2 and 3) that a more depreciated real exchange rate enhances longrun growth.

Another feature from the System GMM growth model is that for the complete sample the estimated coefficients for the two measures of RER misalignment are statistically significant, regardless of which model specification is used, while this is not the case for the developing and emerging market countries sample due to the fact that the Hansen-Diff statistics on previously estimated models suggest that we need to collapse the number of instruments. ${ }^{14}$

\footnotetext{
${ }^{13}$ Figure 1A (appendix) shows the estimated coefficients and significance for a panel regression (fixed effects) of real GDP growth and each one of our nine measures of RER misalignment and it is clear that the coefficients are positive and statistically significant for all estimated models.

${ }^{14}$ We did not report the results for developing and emerging countries without collapsing the number of instruments but they are available on request from the authors. See Roodman (2009) for a further discussion on the consequences of instrument proliferation.
} 
Table 6 - Real GDP Growth - System GMM (Using Panel Cointegration to Estimate Real Exchange Rate Misalignment)

\begin{tabular}{|c|c|c|c|c|c|c|c|c|}
\hline \multirow[b]{2}{*}{ Models } & \multicolumn{4}{|c|}{ Complete Sample } & \multicolumn{4}{|c|}{ Developing and Emerging } \\
\hline & 1 & 2 & 3 & 4 & 1 & 2 & 3 & 4 \\
\hline \multirow[t]{2}{*}{ GrowthPPPlag } & $0.223^{\star \star \star}$ & 0,116 & $0.210^{* * *}$ & $0.136^{*}$ & $0.254^{\star \star *}$ & $0.200^{*}$ & $0.231^{\star \star *}$ & 0,138 \\
\hline & $(2,96)$ & $(1,47)$ & $(2,93)$ & $(1,73)$ & $(2,70)$ & $(1,72)$ & $(3,08)$ & $(1,36)$ \\
\hline \multirow[t]{2}{*}{ Initial Income } & $0.033^{\star \star}$ & 0,004 & $0.024^{*}$ & 0,002 & 0,003 & 0,105 & 0,012 & $0.138^{\star *}$ \\
\hline & $(2,15)$ & $(0,14)$ & $(1,90)$ & $(0,10)$ & $(0,09)$ & $(1,58)$ & $(0,48)$ & $(2,07)$ \\
\hline \multirow[t]{2}{*}{ MisCoint 1} & $0.111^{* *}$ & $0.096^{\star *}$ & & & $0.138^{\star *}$ & 0,147 & & \\
\hline & $(2,45)$ & $(2,37)$ & & & $(2,20)$ & $(1,24)$ & & \\
\hline \multirow[t]{2}{*}{ MisCoint 2} & & & $0.038^{* *}$ & $0.029^{\star *}$ & & & 0,025 & 0,027 \\
\hline & & & $(2,00)$ & $(2,07)$ & & & $(0,89)$ & $(1,10)$ \\
\hline \multirow[t]{2}{*}{ Educ } & & 0,081 & & 0,077 & & $-0,125$ & & $-0,009$ \\
\hline & & $(1,41)$ & & $(1,55)$ & & $(-0.76)$ & & $(-0.05)$ \\
\hline \multirow[t]{2}{*}{ Law } & & $0.028^{\star \star}$ & & $0.031^{\star *}$ & & 0,002 & & 0,024 \\
\hline & & $(1,99)$ & & $(2,06)$ & & $(0,08)$ & & $(1,22)$ \\
\hline \multirow[t]{2}{*}{ Gov } & & $-0.137^{\star \star \star}$ & & $-0.164^{\star \star *}$ & & $-0.276^{\star *}$ & & $-0.343^{\star *}$ \\
\hline & & $(-3.10)$ & & $(-3.11)$ & & $(-1.96)$ & & $(-2.32)$ \\
\hline \multirow[t]{2}{*}{ Inf } & & $-3.9 \mathrm{E}-05^{\star}$ & & $-1,90 \mathrm{E}-05$ & & $-7,20 \mathrm{E}-05$ & & $-2,30 \mathrm{E}-05$ \\
\hline & & $(-1.66)$ & & $(-0.69)$ & & $(-0.96)$ & & $(-0.44)$ \\
\hline $\operatorname{AR}(2)$ & 0,802 & 0,4 & 0,963 & 0,36 & 0,886 & 0,835 & 0,924 & 0,624 \\
\hline Hansen & 0,172 & 0,484 & 0,516 & 0,431 & 0,124 & 0,191 & 0,191 & 0,204 \\
\hline Hansen Diff & 0,773 & 0,732 & 0,833 & 0,575 & 0,541 & 0,101 & 0,592 & 0,04 \\
\hline Number of Groups & 80 & 71 & 77 & 68 & 58 & 49 & 57 & 48 \\
\hline Number of Instruments & 37 & 73 & 37 & 73 & 37 & 35 & 37 & 35 \\
\hline
\end{tabular}

Note: $t$-stat in parenthesis. ${ }^{*},{ }^{* *}$ and ${ }^{* * *}$ indicates significance at $10 \%, 5 \%$ and $1 \%$ respectively. Mis Coint 1 includes LRER and two non-stationary variables (LRGDPCH and NFAGDP).

Mis Coint 2 includes LRER and four variables (LRGDPCH, NFAGDP, LTT and LGOV).

Models 2 and 4 for Developing and Emerging use the Collapse command from Stata 10 to correct for too many instruments.

System GMM 2-step Robust Estimation with Time Dummies.

Econometric Software - Stata 10.

In terms of the magnitude of the estimated coefficients for the two measures of RER misalignment, there are significant differences for the complete and developing / emerging samples, where for the former the coefficients for MIsCointl varies from 0.111 to 0.096 and from 0.138 to 0.147 for the latter. For MisCoint2 the estimated coefficients vary from 0.038 to 0.029 for the complete sample and from 0.025 to 0.027 for developing and emerging economies.

In general, we can infer from our results that a $10 \%$ increase in real exchange rate misalignment increases GDP growth over a five year 
period in the range of $0.29 \%$ to $1.1 \%$ for the complete sample, which translates into annual increases in growth of $0.06 \%$ and $0.22 \%$. For developing and emerging market countries a $10 \%$ increase in RER misalignment increases growth over a five year period in the range of $0.25 \%$ to $1.4 \%$, resulting in annual increases in growth in the range of $0.05 \%$ to $0.28 \% .^{15}$

One final task is to test for non-linearity, taking the same growth regression from Table 6 for our two measures of RER misalignment, and using the squared values of misalignment. The resulting estimated coefficients are negative suggesting that higher levels of RER misalignment reduce long-run growth, but there is no statistical significance in either sample of countries and model specification. ${ }^{16}$ We have not found evidence of non-linearity in the relationship between RER misalignment and growth, which corroborates recent results (Rodrik, 2008) but there is no consensus in the empirical literature since previous studies such as Aguirre and Calderon (2006) and Razin and Collins (1997) have found the existence of non-linearities.

\section{Concluding Remarks}

The empirical literature on growth and real exchange rate misalignment using panel data analysis has developed substantially in the recent past and the evidence suggests that the more depreciated is a country's real exchange the faster is its long-run growth. This result seems to be more significant and robust for emerging and developing countries where institutional fragility and lack of macroeconomic stability is a common feature over the past decades.

The main empirical contribution of our work has been to expand the determinants of the real exchange rate in order to calculate different measures of misalignment and to use two different econometric methodologies (fixed / random effects and panel cointegration analysis) for a set of almost one hundred countries with time series data from 1980 to 2004.

\footnotetext{
15 One comparison that can be made for the estimated coefficients of RER misalignments relates to two sets of estimates which use the same model specification: one is between Mis2 and MisCointl and the second is for Mis5 and MisCoint2. See Tables 2, 3 and 6.

16 The estimated coefficients for MisCoint 1 and MisCoint 2 squared are not reported due to lack of statistical significance but they are available from the authors on request.
} 
Our empirical estimation of the System GMM panel growth models has shown that all estimated coefficients for the real exchange rate misalignment are positive, which means that a more real depreciated exchange rate helps real GDP growth while the opposite is true for a real exchange rate appreciation. The results are robust in terms of statistically significant coefficients for different samples and models and the estimated coefficients are higher for developing and emerging market economies. The estimated coefficients from all of our nine measures of real exchange rate misalignment suggest that a $10 \%$ increase (depreciation) in real exchange rate misalignment can increase annual per capita GDP growth by up to $0.3 \%$.

Finally, we can say that our results are in accordance with those reported in recent studies, such as Rodrik (2008) and Berg and Miao (2010), although we find that exchange rate misalignment has a bigger impact on economic growth than that reported in these studies. The crucial policy recommendation to stem from our work, which is especially relevant for developing and emerging market economies, is that such economies should avoid periods of long lasting real exchange rate appreciation and instead adopt economic policies that are able to keep the real exchange rate at a competitive level, which most of the time should be associated with a more depreciated real exchange rate relative to its equilibrium level.

\section{References}

AGHION, P.; BACCHETTA, P.; RANCIERE, R.; ROGOFF, K. Exchange Rate Volatility and Productivity Growth: The Role of Financial Development. NBER Working Paper No. 12117, 2006.

AGUIRRE, A.; CALDERÓN, C. Real Exchange Rate Misalignments and Economic Performance. Central Bank of Chile, Economic Research Division, Working Paper 315, 2006.

ARELlAnO, M.; BOND, S. Some Tests of Specification for Panel Data: Monte Carlo Evidence and an Application to Employment Equations. Review of Economic Studies 58(2), p.277-297, 1991.

ARELLANO, M.; BOVER, O. Another Look at the Instrumental-Variable Estimation of Error-Components Models. Journal of Econometrics 68(1), p.29-51, 1995.

BALASSA, B. The Purchasing Power Parity Doctrine: A Reappraisal. The Journal of Political Economy, 72, p.584-596, 1964.

BARRO, R. J.; LEE, J.W. International Data on Educational Attainment: Updates and Implications. Center for International Development Working Paper No. 42, Harvard University, 2000.

BERG, A.; MIAO, Y. The Real Exchange Rate and Growth Revisited: The Washington Consensus Strikes Back? IMF Working Paper, 10 (58), 2010.

BLUNDELL, R.; BOND, S. Initial conditions and moment restrictions in dynamic panel data models. Journal of Econometrics 87(1), p.115-143, 1998. 
CHOI, I. Unit Root Tests for Panel Data. Journal of International Money and Finance, 20, p.249-272, 2001.

CLARK, P. B.; MACDONALD, R. Exchange rates and economic fundamentals: A methodological comparison of BEERs and FEERs. IMF Working Paper, 98 (67), 1998.

COUDERT, V.; COUHARD, C. Currency Misalignments and Exchange Rate Regimes in Emerging and Developing Countries. CEPII Working Papers, No. 7, 2008.

EDWARDS, S. Exchange Rate Misalignment in Developing Countries. Baltimore, MD: Johns Hopkins University Press, 1988.

EDWARDS, S.; SAVASTANO, M. Exchange Rates in Emerging Economies: What do We Know? What do We Need to Know? NBER Working Paper No. 7228, 1999.

EICHENGREEN, B. The Real Exchange Rate and Economic Growth. Commission on Growth and Development Working Paper, No. 4, The World Bank, 2008.

FRANKEL, J. A.; ROSE, A. K. Currency crashes in emerging markets: An empirical treatment. Journal of International Economics, 41(3-4), p.351-366, 1996.

GALA, P.; LUCINDA, C. R. Exchange Rate Misalignment and Growth: Old and New Econometric Evidence. Revista Economia, p.165-87, 2006.

HADRI, K. Testing for Stationarity in Heterogeneous Panel Data, Econometric Journal, 3, p. 148-161, 2000.

HAUSMANN, R.; PRITCHETT, L.; RODRIK, D. Growth Accelerations. Journal of Economic Growth, 10 (4), p.303-329, 2005.

HESTON, A.; SUMMERS, R.; BETTINA, A. Penn World Table Version 6.2, Center for International Comparisons of Production, Income and Prices at the University of Pennsylvania, 2006. http:// pwt.econ.upenn.edu/php_site/pwt_index.php. Accessed 19 February 2010.

IM, K. S.; PESARAN, M. H.; SHIN, Y. Testing for unit roots in heterogeneous panels. Journal of Econometrics, 115 (1), p.53-74, 2003.

KAO, C. Spurious Regression and Residual-Based Tests for Cointegration in Panel Data. Journal of Econometrics, 90, p.1-44, 1999.

LANE, P.; MILESI-FERRETTI, G. M. The External Wealth of Nations Mark II: Revised and Extended Estimates of Foreign Assets and Liabilities 1970-2004. Journal of International Economics, 73, p.223-250, 2007.

LEVIN, A.; LIN, C. F.; CHU, C. Unit Root Tests in Panel Data: Asymptotic and Finite-Sample Properties. Journal of Econometrics, 108, p.1-24, 2002.

MADDALA, G. S.; WU, S. Comparative Study of Unit Root Tests with Panel Data and a New Simple Test. Oxford Bulletin of Economics and Statistics, 61 (1), p.631-652, 1999.

PEDRONI, P. Critical Values for Cointegration Tests in Heterogeneous Panels with Multiple Regressors, Oxford Bulletin of Economics and Statistics, 61, p.653-70, 1999.

PEDRONI, P. Panel Cointegration; Asymptotic and Finite Sample Properties of Pooled Time Series Tests with an Application to the PPP Hypothesis. Econometric Theory, 20, p.597-625, 2004.

RAZIN, O.; COLLINS, S. M. Real Exchange Rate Misalignments and Growth. Real Exchange Rate Misalignments and Growth. NBER Working Paper No. 6174, 1997.

RODRIK, D. The Real Exchange Rate and Economic Growth. Brookings Papers on Economic Activity, 2, p.365-412, 2008.

ROODMAN, D. A Note on the Theme of Too Many Instruments. Oxford Bulletin of Economics and Statistics, 71(1), p.135-158, 2009. 


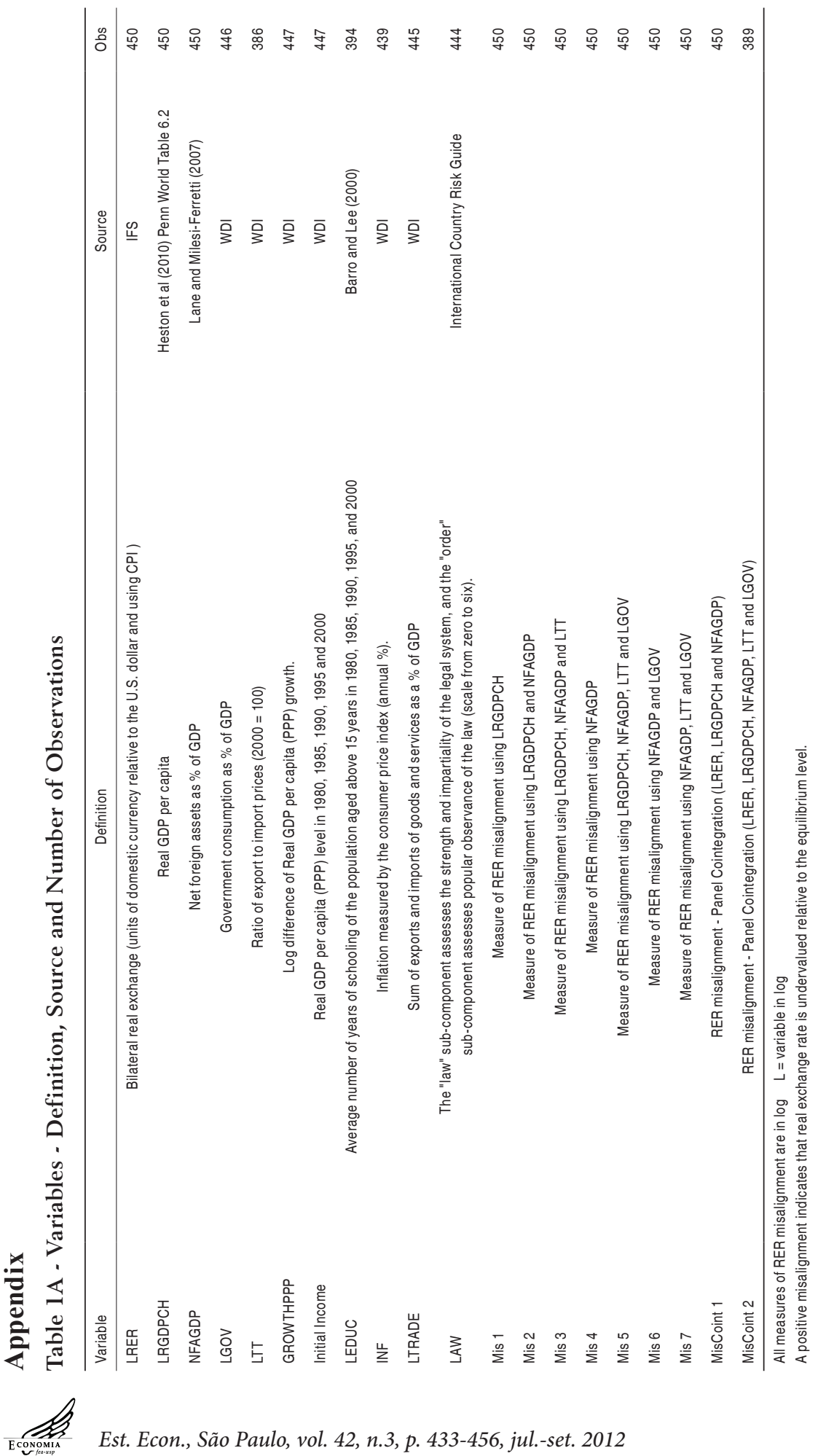


Table 2A - List of Countries - Complete Sample

\begin{tabular}{|c|c|c|c|c|}
\hline Countries & Countries & Countries & Countries & Countries \\
\hline Algeria & Costa Rica & Iceland & Mexico & Singapore \\
\hline Argentina & Cote D Ivoire & India & Morocco & South Africa \\
\hline Australia & Denmark & Indonesia & Netherlands & Spain \\
\hline Austria & Dominican Republic & Iran & New Zealand & Sri Lanka \\
\hline Bahrain & Ecuador & Ireland & Nicaragua & Sudan \\
\hline Bangladesh & Egypt & Israel & Niger & Sweden \\
\hline Belgium & El Salvador & Italy & Nigeria & Switzerland \\
\hline Bolivia & Ethiopia & Jamaica & Norway & Syria \\
\hline Botswana & Finland & Japan & Oman & Thailand \\
\hline Brazil & France & Jordan & Pakistan & Togo \\
\hline Burkina Faso & Gabon & Kenya & Panama & Trinidad \& Tobago \\
\hline Cameroon & Germany & Korea, South & Papua New Guinea & Tunisia \\
\hline Canada & Ghana & Kuwait & Paraguay & Turkey \\
\hline Chile & Greece & Madagascar & Peru & Uganda \\
\hline China & Guatemala & Malawi & Philippines & United Kingdom \\
\hline Colombia & Haiti & Malaysia & Portugal & Uruguay \\
\hline Congo & Honduras & Mali & Saudi Arabia & Venezuela \\
\hline Congo, DR & Hong Kong & Malta & Senegal & Zambia \\
\hline
\end{tabular}



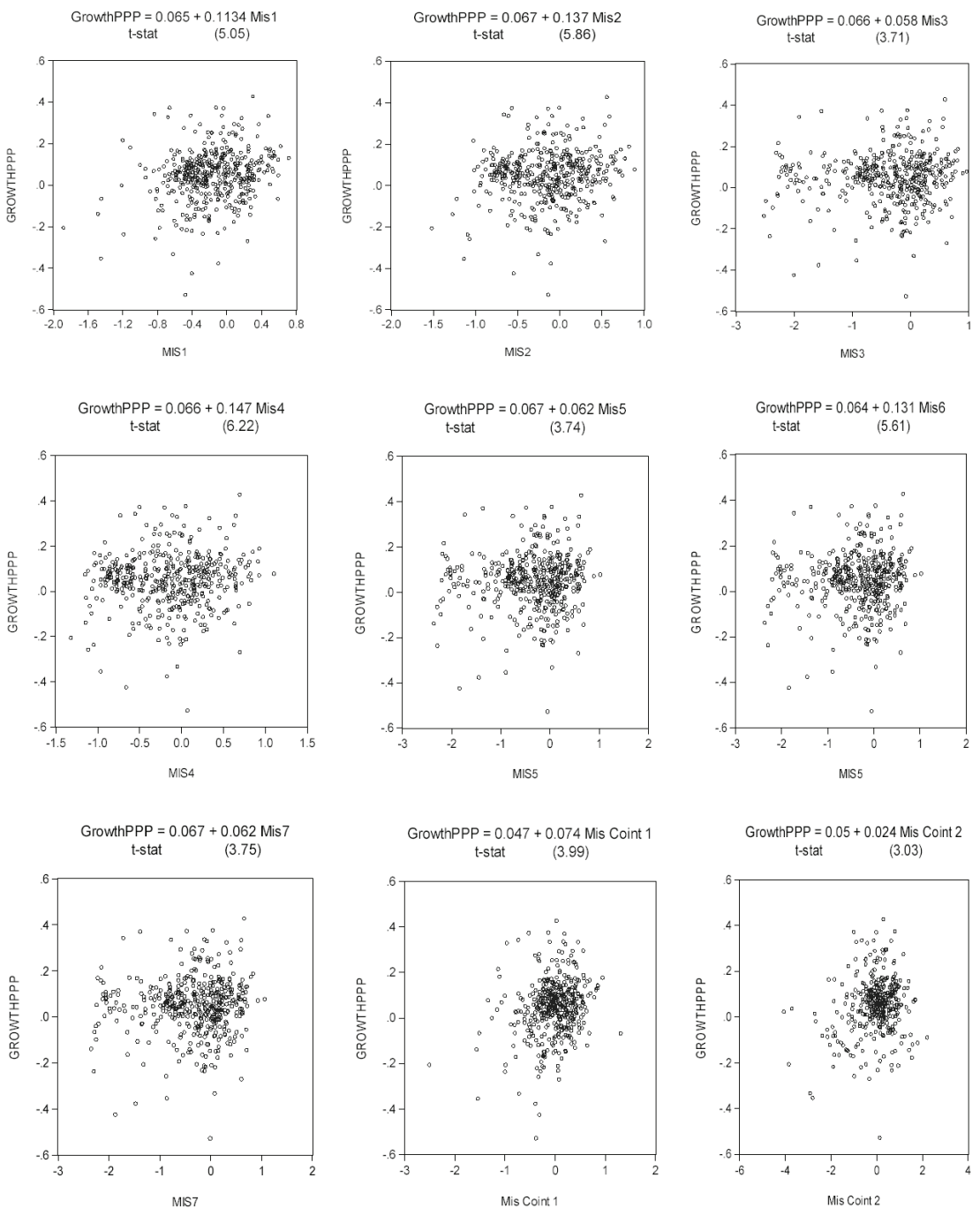

Figure 1A - Growth and RER Misalignment - Panel Regression (Fixed Effects) Note: Econometric Software - Stata 10. 